\title{
HUBUNGAN STATUS GIZI DENGAN KUALITAS HIDUP LANSIA DI WILAYAH PUSKESMAS MADISING NA MARIO KOTA PAREPARE
}

\author{
Relationship of Nutritional Status With The Quality of Life Elderly in Madising \\ Na Mario Health Center Parepare City
}

Indah Pratiwi, Haniarti, Herlina Muin

(Program Studi Kesehatan Masyarakat Fakultas Ilmu Kesehatan Universitas Muhammadiyah Parepare) (indahpratiwi9792@gmail.com)

\begin{abstract}
ABSTRAK
Status gizi dikatakan baik bila pola makan kita seimbang. Artinya, asupan, frekuensi dan jenis makanan yang dikomsumsi harus sesuai dengan kebutuhan tubuh. Menurut World Health Organization Quality of Life (WHOQOL), Kualitas Hidup adalah kondisi fungsional lansia yang meliputi Kesehatan fisik, kesehatan psikologis, hubungan sosial, dan hubungan lingkungan. Tujuan penelitian ini untuk menunjukkan adakah hubungan status gizi dengan kualitas hidup lansia di tinjau dari kesehatan fisik, kesehatan psikologis, kondisi sosial, kondisi lingkungan di Wilayah Kerja Puskesmas Madising Na Mario Kota Pare - Pare. Metode yang digunakan dalam penelitian ini adalah metode analitik dengan pendekatan cross sectional study. Peneliti mengidentifikasi melalui obeservasional dengan menggunakan kuesioner pada sampel, dimana sampel dalam penelitian ini sebanyak 89 orang. Data dianalisis secara univariat dan bivariat menggunakan uji chi square melalui SPSS Versi 24. Hasil penelitian menunjukkan bahwa ada hubungan kesehatan fisik $(0,009<0,05)$, tidak ada hubungan kesehatan psikologis $(0,450>0,05)$, ada hubungan kondisi sosial $(0,014<0,05)$, tidak hubungan kondisi lingkungan $(0,241>0,05)$ dengan status gizi lansia di Wilayah Kerja Puskesmas Madising Na Mario Kota Parepare.
\end{abstract}

\section{Kata Kunci : Status gizi, kesehatan fisik, kesehatan psikologis, kondisi sosial, kondisi lingkungan}

\begin{abstract}
Nutritional status is said to be good if our diet is balanced. That is, the intake, frequency and type of food consumed must be in accordance with the body's needs. According to the World Health Organization Quality of Life (WHOQOL), Quality of Life is a functional condition of the elderly which includes physical health, psychological health, social relations, and environmental relations. The purpose of this study is to show whether there is a relationship between nutritional status and the quality of life of the elderly in terms of physical health. , psychological health, social conditions, environmental conditions in the Community Health Center Working Area Madising Na Mario City of Pare - Pare. The method used in this study is an analytical method with a cross sectional study approach. Researchers identified through obesity by using a questionnaire in the sample, where the sample in this study were 89 people. Data were analyzed by univariate and bivariate using chi square test through SPSS Version 24. The results showed that there was a relationship of physical health $(0.009<0.05)$, there was no psychological
\end{abstract}


health relationship $(0.450>0.05)$, there was a relationship of social conditions $(0.014<0.05)$, there is no correlation between environmental conditions $(0.241>0.05)$ with the nutritional status of the elderly in the Madising Na Health Center Working Area of Parepare City.

Keywords: Nutritional status, physical health, psychological health, social conditions, environmental conditions 


\section{PENDAHULUAN}

Status gizi adalah keadaan tubuh yang merupakan refleksi dari apa yang kita makan sehari-hari. Status gizi dikatakan baik bila pola makan kita seimbang. Artinya, asupan, frekuensi dan jenis makanan yang dikomsumsi harus sesuai dengan kebutuhan tubuh. Bila komsumsi makanan melebihi kebutuhan, tubuh akan mengalami kegemukan. Sebaliknya, asupan makanan kurang dari yang dibutuhkan, tubuh akan menjadi kurus dan sakit-sakitan. Kegemukan juga tidak berarti sehat karena dapat memacu timbulnya berbagai penyakit. Status gizi kurang atau status gizi lebih akan berdampak kurang baik terhadap kesehatan tubuh. Kedua keadaan tersebut dinamakan status gizi salah. ${ }^{1}$

\section{Menurut World Health Organization} Quality of Life (WHOQOL), Kualitas Hidup adalah kondisi fungsional lansia yang meliputi Kesehatan Fisik yaitu aktivitas sehari-hari, ketergantungan pada bantuan medis, kebutuhan istirahat, kegelisahan tidur, penyakit, energi, kelelahan, mobilitas, kapasitas pekerjaan. Kesehatan Psikologis yaitu perasaan positif, penampilan dan gambaran jasmani, perasaan negatif, berfikir, belajar, konsentrasi, mengingat, dan kepercayaan individu, Hubungan Sosial lansia yaitu dukungan sosial, hubungan pribadi, serta aktivitas seksual, dan Kondisi Lingkungan yaitu lingkungan rumah, kebebasan, keselamatan fisik, aktivitas di lingkungan, kendaraan, keamanan, sumber keuangan, kesehatan dan kepedulian sosial.
Kualitas hidup dipengaruhi oleh tingkat kemandirian, kondisi fisik dan psikologis, aktifitas sosial, interaksi sosial dan fungsi keluarga. Pada umumnya lanjut usia mengalami keterbatasan, sehingga kualitas hidup pada lanjut usia menjadi mengalami penurunan perubahan yang terjadi pada responden akibat penurunan kualitas hidup antara lain cepat capai, lelah, pusing, berkeringat, mengalami kesulitan tidur sehingga waktu tidur menjadi kurang, menjadi mudah tersinggung dan perasaan minder untuk bergaul dengan lingkungan. ${ }^{2}$ Masalah kualitas hidup semakin mendapat perhatian di negara-negara maju disamping masalah kesehatan yang selama ini muncul. Kualitas hidup dalam konteks populasi sering di jadikan evaluasi terhadap intervensi dan studi klinis.

Puskesmas Madising $\mathrm{Na}$ Mario membuat program untuk para lansia yang diberi nama "Klub Prolanis". Dimana program tersebut bekerjasama Antara Puskesmas Madisi Na Mario dan BPJS. Klub ini hadir sebagai upaya promosi kesehatan yang dididalamnya ada edukasi/penyuluhan, senam, pemeriksaan kesehatan secara rutin untuk memaksimalkan pelayanan kesehatan bagi peserta BPJS.

Data dari Puskesmas Madising $\mathrm{Na}$ Mario jumlah lansia yang terdaftar adalah 2.401 orang. Diantaranya Pra usila sebanyak 1.365 orang, usila sebanyak 773 orang, dan usila resti 263 orang dari jumlah lansia tersebut yang berkunjung untuk 
memeriksakan kesehatan secara rutin adalah 130 sampai 140 orang dari banyaknya lansia yang berkunjung hanya 42 orang yang dari Wilayah Kerja Puskesmas Madising Na Mario.

\section{METODE PENELITIAN}

Metode penelitian yang digunakan dalam penelitian ini adalah analitik observasional dengan rancangan cross sectional study, dilakukan di wilayah kerja Puskesmas Madising Na Mario Kota Parepare. Yang akan dilaksanakan pada bulan April - Juli 2018. Instrumen alam pelaksanaan penelitian ini dilakukan observasi langsung kelapangan dan menyebarkan kuesioner. yang akan dibagikan kepada responden berkaitan dengan kualitas hidup lansia. Untuk mengukur Status Gizi menggunakan Meter untuk mengukur tinggi badan, timbangan badan digital sedangkan sampel yaitu yang berumur 60-74 tahun sebanyak 89 orang, pengambilan sampel dengan metode simple random sampling.

\section{HASIL PENELITIAN}

Penelitian ini dilakukan di Wilayah Kerja Puskesmas Madising Na Mario Kota Parepare pada tanggal Juli sampai Agustus 2018. Dimana di Wilayah Kerja Puskesmas Madising Na Mario Kota Parepare terdapat dua kelurahan di antaranya yaitu Kelurahan Mallusetasi dan Kelurahan Labukkang, dimana jumlah penduduknya 4.779 orang. Diantaranya terdapat lansia sebanyak 2.401 orang terbagi 3 kelompok yaitu Pra usila sebanyak 1.365 orang, usila sebanyak 773 orang, dan usila resti 263 orang . Proses pengambilan data dilakukan dengan menggunakan kuesioner berupa pertanyaan kepada responden dan alat yang digunakan berupa timbangan digital untuk mengetahui berat badan responden dan pengukuran tinggi badan.

Data dari hasil penelitian diolah berdasarkan langkah-langkah pengelolahan data dianalisis menggunakan komputer dengan program SPPS (Statistical Product And Service Solution) versi 24 kemudian disajikan dalam bentuk tabel dan narasi seperti berikut.

Tabel 1 menunjukkan bahwa dari total 89 responden, umur responden yang tertinggi terdapat pada kelompok umur 7074 tahun yaitu sebanyak 34 orang $(38,8 \%)$ dan umur yang terendah terdapat pada kelompok umur 60-64 tahun yaitu sebanyak 26 orang ( 26,2\%). Yang berjenis kelamin laki-laki sebanyak 37 orang $(41,6 \%)$ dan responden yang berjenis kelamin perempuan sebanyak 52 orang $(58,4 \%)$. Pendidikan terakhir responden yang tertinggi terdapat pada jenjang pendidikan SD sebanyak 30 orang $(33,7 \%)$ dan pendidikan terakhir responden yang terendah terdapat pada jenjang pendidikan sarjana(S1) sebanyak 3 orang $(3,4 \%)$. Status pekerjaan responden yang tertinggi terdapat pada tidak memiliki pekerjaan sebanyak 71 orang $(79,8 \%)$ dan status pekerjaan responden yang terendah terdapat pada pekerjaan sebagai buruh cuci 
sebanyak 1 orang $(1,1 \%)$, buruh/kuli bangunan sebanyak 1 orang $(1,1 \%)$. Status tinggal responden yang tertinggi yaitu tinggal bersama keluarga besar sebanyak 67 orang $(75,3 \%)$ dan status tinggal responden yang terendah yaitu tinggal sendiri sebanyak 7 orang $(7,9 \%)$ untuk Tabel 2 menunjukkan bahwa dari total 89 responden, responden yang memliki status gizi normal sebanyak 63 orang $(70,8 \%)$ dan yang memilki status gizi tidak normal sebanyak 26 orang $(29,2 \%)$.

Tabel 3 responden yang memiliki kesehatan fisik baik sebanyak 36 orang $(40,4 \%)$ dan Kesehatan tidak baik sebanyak 53 orang $(59,6 \%)$. Responden yang memiliki kesehatan psikologis baik sebanyak 39 orang $(43,8 \%)$ dan kesehatan psikologis tidak baik sebanyak 50 orang $(56,2 \%)$. Responden yang memiliki kondisi sosial baik sebanyak 37 orang $(41,6 \%)$ dan kondisi sosial tidak baik sebanyak 52 orang $(58,4 \%)$. Responden yang memiliki kondisi lingkungan baik sebanyak 68 orang $(76,4 \%)$ dan kondisi lingkungan tidak baik sebanyak 21 orang $(23,6 \%)$.

Tabel 4 responden yang memiliki status gizi normal, 20 orang $(55,6 \%)$ yang kesehatan fisik baik dan 43 orang $(81,1 \%)$ yang kesehatan fisik tidak baik, Sedangkan yang memiliki status gizi tidak normal, 16 orang $(44,4 \%)$ yang kesehatan fisik baik dan 10 orang $(18,9 \%)$ yang kesehatan fisik tidak baik. Berdasarkan hasil uji chi-square di peroleh nilai $\mathrm{p}$ value $(0,009)<(0,05)$ maka $\mathrm{H}_{\mathrm{a}}$ diterima dan $\mathrm{H}_{0}$ ditolak sehingga disimpulkan bahwa ada hubungan status gizi dengan kualitas hidup ditinjau dari kesehatan fisik pada lansia di wilayah Puskesmas Madising Na Mario Kota Parepare.

Tabel 5 responden yang memiliki status gizi normal, 26 orang $(66,7 \%)$ yang kesehatan psikologis baik dan 37 orang (74,0\%) yang kesehatan psikolgis tidak baik, Sedangkan yang memiliki status gizi tidak normal, 13 orang $(33,3 \%)$ yang kesehatan psikologis baik dan 13 orang $(26,0 \%)$ yang kesehatan psikologis tidak baik. Berdasarkan hasil uji chi-square di peroleh nilai $\mathrm{p}$ value $(0,450)<(0,05)$ maka $\mathrm{H}_{\mathrm{a}}$ ditolak dan $\mathrm{H}_{0}$ diterima sehingga disimpulkan bahwa tidak ada hubungan status gizi dengan kualitas hidup ditinjau dari kesehatan psikologis pada lansia di wilayah Puskesmas Madising $\mathrm{Na}$ Mario Kota Parepare.

Tabel 6 responden yang memiliki status gizi normal, 21 orang $(56,8 \%)$ yang kondisi sosial baik dan 42 orang $(80,8 \%)$ yang kondisi sosial tidak baik, Sedangkan yang memiliki status gizi tidak normal, 16 orang $(43,2 \%)$ yang kondisi sosial baik dan 10 orang $(19,2 \%)$ yang kondisi sosial tidak baik. Berdasarkan hasil uji chi-square di peroleh nilai $\mathrm{p}$ value $(0,014)<(0,05)$ maka $\mathrm{H}_{\mathrm{a}}$ diterima dan $\mathrm{H}_{0}$ ditolak sehingga disimpulkan bahwa ada hubungan status gizi dengan kualitas hidup ditinjau dari kondisi sosial pada lansia di wilayah Puskesmas Madising Na Mario Kota Parepare.

Tabel 7 responden yang memiliki status gizi normal, 46 orang $(67,6 \%)$ yang kondisi lingkungan baik dan 17 orang 
$(81,0 \%)$ yang kondisi lingkungan tidak baik, Sedangkan yang memiliki status gizi tidak normal, 22 orang $(32,4 \%)$ yang kondisi lingkungan baik dan 4 orang (19,0\%) yang kondisi lingkungan tidak baik. Berdasarkan hasil uji chi-square di peroleh nilai $\mathrm{p}$ value $(0,241)<(0,05)$ maka $\mathrm{H}_{\mathrm{a}}$ ditolak dan $\mathrm{H}_{0}$ diterima sehingga disimpulkan bahwa tidak ada hubungan status gizi dengan kualitas hidup ditinjau dari kondisi lingkungan pada lansia di wilayah Puskesmas Madising $\mathrm{Na}$ Mario Kota Parepare.

\section{PEMBAHASAN}

Hasil penelitian ini yang telah dilakukan tentang status gizi dengan kualitas hidup lansia diwilayah kerja puskesmas madising na Mario koat parepare. Maka ditinjau dari karakteristik responden berdasarkan kelompok umur diketahui mereka berada pada usia produktif, dimana seharusnya manusia dapat bekerja dan menghasilkan kelangsungan hidupnya. Tetapi, apabila lansia semakin bertambah usianya maka asupan zat gizinya mengalami penurunan.

Penentuan karakteristik status gizi ada 3 yaitu gizi kurang ( >18,5), gizi normal $(18,5-25,0)$, gizi lebih $(>25,0)$. Penulis menggabung gizi kurang dan gizi lebih menjadi tidak normal sedangkan gizi normal tetap normal agar dapat memenuhi syarat di uji chi square versi 24. Ditinjau dari analisis karakteristik responden berdasarkan jenis kelamin diketahui responden yang berjenis kelamin perempuan lebih banyak dari pada laki-laki karena dimana semua ibu rumah tangga (IRT) yang lebih memilih tinggal bersama keluarga besarnya yaitu anak dan cucuknya.

Selanjutnya ditinjau dari analisis karakteristik responden berdasarkan tingkat pendidikan terakhir responden dari hasil penelitian ini pendidikan yang terabaik terbanyak yaitu SD. Jika dilihat dari tingkat pendidikan yang ditimpuh, seharusnya responden sudah mempunyai pengetahuan dan pemahaman yang cukup mengenai asupan gizi yang baik meskipun bertambahnya usia mereka. Tapi nyatanya jenjang pendidikan tidak terlalu berpengaruh terhadap perilaku hidup sehat lansia. Hal ini membuktikan bahwa penyebab tersebut semakin bertambahnya usia akan mempengaruhi kualitas hidup menurun.

Kesehataan fisik dimana Kemampuan seseorang untuk menunaikan tugasnya sehari-hari dengan gampang, tanpa merasa lelah yang berlebihan, serta masih mempunyai sisa atau cadangan tenaga untuk menikmati waktu senggangnya dan untuk keperluan-keperluan mendadak. dengan kata lain Kesegaran jasmani dapat pula didefinisikan sebagai kemampuan untuk menunaikan tugas dengan baik walaupun dalam keadaan sukar, dimana orang yang kesegaran jasmaninya kurang, tidak akan dapat melakukannya.

Berdasarkan hasil uji chi-square di peroleh nilai $p$ value $(0,009)<(0,05)$ maka $\mathrm{H}_{\mathrm{a}}$ diterima dan $\mathrm{H}_{0}$ ditolak sehingga disimpulkan bahwa ada hubungan status gizi 
dengan kualitas hidup ditinjau dari kesehatan fisik pada lansia di wilayah Puskesmas Madising Na Mario Kota Parepare. Dari hasil wawancara dengan mengisi kuesioner, peneliti menemukan bahwa kebanyak responden yang status gizi tidak normal memberikan jawaban mengarah kesehatan fisiknya baik disebabkan banyaknya melakukan aktivitas didalam atau diluar rumah. Berdasarkan observasi langsung yang dilakukan peneliti di kediaman responden kebanyakan status gizinya normal kurang melakukan aktivitas sehari-hari disebabkan responden tidak kuat lagi melakukan aktivitas tersebut. Sedangkan beberapa status gizi tidak normal justru sebaliknya dapat melakukan aktivitas seharihari agar mereka kesehaan fisiknya tidak menurun seiringan usia mereka bertambah.

Hasil tersebut relevan dengan penelitian yang dilakukan oleh Ardli Hidayat (2017) bahwa kesehatan fisik memengaruhi kualitas hidup pada lansia. ${ }^{3}$ Diperkuat oleh hasil penelitian Fitri Andaru Adhi Astuti (2012) bahwa status gizi mempengaruhi kesehatan fisik Status gizi geriatri pada umumnya dipengaruhi oleh asupan makanan, kurangnya pengetahuan akan pentingnya gizi yang baik. Sedangkan kualitas hidup di pengaruhi oleh empat domain yang salah satunya adalah kesehatan fisik yang termasuk di dalamnya adalah aktivitas fisik yaitu berolahraga, membersihkan rumah, memasak, dan beribadah. ${ }^{4}$
Hasil penelitian ini sejalan dengan yang dilakukan oleh Wa Ode Sarnings (2012) yang mendapatkan adanya hubungan status gizi dengan kualitas hidup lansia di Kabupaten Barru Kecamatan Sopengriaja dan Mallausetasi dimana hasil uji chi-square nilai $p$ value $0,00<0,05$ yang berarti ada adanya hubungan status gizi dengan kualitas hidup lansia di Kabupaten Barru Kecamatan Sopengriaja dan Mallusetasi. ${ }^{5}$ Kesehatan psikologis adalah kemampuan individu untuk bekerja secara produktif dan bermanfaat bagi diri sendiri dan orang lain. berdasarkan keimanan dan ketakwaan serta bertujuan untuk mencapai hidup bermakna dan bahagia di dunia dan akhirat.

Berdasarkan hasil uji chi-square diperoleh nilai $p$ value $(0,450)>(0,05)$ maka $\mathrm{H}_{\mathrm{a}}$ ditolak dan $\mathrm{H}_{0}$ diterima sehingga disimpulkan bahwa tidak hubungan status gizi dengan kualitas hidup lansia di tinjau dari kesehatan psikologis pada lansia di Wilayah Puskesmas Madising Na Mario Kota Parepare. Pada saat penelitian, peneliti menemukan bahwa kebanyakan responden menunjukkan bahwa kemampuaan mengeksperikan emosinya, rasa syukur, pujian, dan kepercayaan dapat diterima oleh keluarga dan sekitarnya.

Hasil tersebut relevan dengan penelitian yang dilakukan oleh Agustien (2008) yang mengatakan bahwa tidak ada hubungan antara kondisi psikologis dengan status gizi pada lansia. ${ }^{6}$ Hasil penelitian ini sejalan dengan yang dilakukan oleh Reni Zulfitri (2015) pengaruh kesejahteraan 
psikologis lansia terhadap status gizi lansia di kelurahan meranti pandak pekanbaru. dimana uji chi-square nilai $p$ value 0,511 > 0,05 menunjukkan bahwa tidak ada pengaruh signifikan antara kesejahteraan

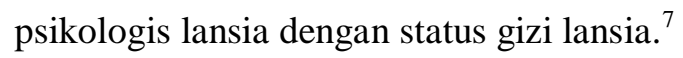

Kondisi sosial adalah suatu kondisi tertentu dimana berlangsung hubungan antara individu yang satu dengan individu yang lain atau terjadi saling hubungan antara dua individu atau lebih. Berdasarkan hasil uji chi-square di peroleh nilai $\mathrm{p}$ value $(0,014)<(0,05)$ maka $\mathrm{H}_{\mathrm{a}}$ diterima dan $\mathrm{H}_{0}$ ditolak sehingga disimpulkan bahwa ada hubungan status gizi dengan kualitas hidup ditinjau dari kondisi sosial pada lansia di wilayah Puskesmas Madising Na Mario Kota Parepare.

Dari hasil wawancara dengan mengisi kuesioner, peneliti menemukan bahwa kebanyakan dari responden memberi jawaban yang mengarah kurang bersosialisasi sekitar lingkungannya. Berdasarkan pengamatan yang di lakukan di lokasi penelitian, peneliti menemukan bahwa kebanyakan responden menggunakan waktunya untuk melakukan kegiatan bersama keluarga agar responden merasa menjadi percaya diri saat berkumpul dengan keluarga.

Secara umum bisa dikatakan setiap perbuatan yang dilakukan oleh seseorang adalah sosial. Sebab pekerjaan tersebut selalu menimbulkan respon terhadap orang lain. Jika kita lanjutkan pembicaraan tentang individu, individu selalu dan mesti berhubungan dengan lingkungan. Hubungan antara individu tersebut sering berupa adaptasi. Yaitu manusia menyesuaikan diri dengan lingkungan.

Orang yang hidup dalam lingkungan yang bersikap suportif, kondisinya jauh lebih baik dari pada mereka yang tidak memilikinya. Dukungan tersebut akan tercipta bila hubungan interpersonal diantara mereka baik. Status gizi pada lansia sangat dipengaruhi oleh dukungan keluarga dengan memberikan dukungan yang positif dapat memberikan kesehatan bagi lansia. Keluarga merupakan support system utama bagi lansia dalam mempertahankan kesehatannya.

Hasil penelitian ini sejalan dengan penelitian dilakukan oleh Wiwidya Ningsih (2013) ada hubungan antara dukungan keluarga dengan status gizi lansia di Dusun Jodog Kelurahan Gilangharjo Pandak Bantul yang menunjukkan hubungan gizi pada lansia dapat dilihat dari berbagai aspek struktur sosial dapat mempengaruhi kesehatan lansia itu sendiri. ${ }^{8}$ Berdasarkan hasil uji chi-square di peroleh nilai $p$ value $(0,241)<(0,05)$ maka $\mathrm{H}_{\mathrm{a}}$ ditolak dan $\mathrm{H}_{0}$ diterima sehingga disimpulkan bahwa tidak ada hubungan status gizi dengan kualitas hidup ditinjau dari kondisi lingkungan pada lansia di wilayah Puskesmas Madising $\mathrm{Na}$ Mario Kota Parepare. Dari hasil wawancara dengan mengisi kuesioner, peneliti menemukan bahwa kebanyakan dari responden memberi jawaban yang mengarah 
kondisi lingkungan tempat tinggal responden baik.

Berdasarkan pengamatan yang dilakukan di lokasi penelitian, peneliti berasumsi bahwa meskipun jangkauan tempat tinggal responden tidak memungkinkan tetapi responden memiliki cara untuk bagaimana cara hidup sehat disekitar lingkungan responden tinggal. Setiap orang memiliki kebutuhan hidup. Orang lanjut usia juga memiliki kebutuhan hidup yang sama agar dapat hidup sejahtera. Kebutuhan hidup lanjut usia antara lain kebutuhan akan makanan bergizi seimbang, pemeriksaan kesehatan secara rutin, perumahan yang sehat dan kondisi rumah yang tentaram dan aman, kebutuhankebutuhan sosial seperti bersosialisasi dengan semua orang dalam segala usia, sehingga mereka mempunyai banyak teman yang dapat di ajak berkomunikasi, membagi pengalaman, memberikan pengarahan untuk kehidupan yang baik. Kebutuhan tersebut diperlukan oleh lanjut usia agar dapat mandiri.

Hal ini berbeda dengan penelitian yang dilakukan oleh Suwignyo, Eka R nia SNL, Nefri T, Suryanti (2017) menemukan bahwa lansia memiliki status gizi baik $(48,5 \%)$ mempengaruhi tempat tinggal responden yang nilai uji $p$ value $0,003<0,05$ yang berarti ada hubungan yang bermakna antara status gizi dengan tempat tinggal lansia di panti sosial dengan komplek perumahan. ${ }^{9}$

\section{KESIMPULAN DAN SARAN}

Berdasarkan hasil penelitian yang dilakukan mengenai hubungan status gizi dengan kualitas hidup lansia di Wilayah Kerja Puskesmas Madising Na Mario Kota Parepare maka diperoleh kesimpulan sebagai berikut, ditinjau dari kesehatan fisik ada hubungan status gizi dengan kualias hidup lansia, untuk kesehatan psikologis tidak ada hubungan status gizi dengan kualias hidup lansia, dilihat dari kondisi sosial ada hubungan status gizi dengan kualias hidup lansia, sedangkan ditinjau dari kondisi lingkungan tidak ada hubungan status gizi dengan kualias hidup lansia di Wilayah Kerja Puskesmas Madising Na Mario Kota Parepare.Berdasarkan kesimpulan dapat disarankan bagi para lansia diharapkan mampu melakukan aktivitas sehari-hari untuk dapat melatih tubuh agar kualitas hidup menjadi lebih baik meskipun bertambah usia, Bagi keluarga diharapkan untuk bisa memberi dukungan terhadap lansia berupa perhatian, berbagi perasaan dan menghargai satu sama lain, Bagi masyarakat disekitar lingkungannya diharapkan untuk bisa menerima, bergaul dan berteman dengan sesamanya tanpa ada perlakuan yang berbeda di sekitar lingkungannya, Bagi petugas kesehatan peran aktif memberikan dukungan dan pelayanan yang baik pada lansia untuk kelangsungan hidupnya. Petugas kesehatan juga sebaiknya melakukan sosialisasi mengenai kualitas hidup yang baik. 


\section{DAFTAR PUSTAKA}

1. Astawan. 2008. Status Gizi. [Di Akses tanggal 25 April 2018].

2. Yuliastuti C, Anggoro SD. Gambaran Profil Gaya Hidup Lanjut Usia Di Wilayah Surabaya. Jurnal Keperawatan Stikes Hang Tuah Surabaya; 2016: $10(1)$.

3. Hidayat A. Hubungan Aktivitas Fisik dengan Kualitas Hidup Lansia di Posyandu Desa Selokerto Kecamatan Sempor Kabupaten Kebumen [Skripsi]. Sekolah Tinggi Ilmu Kesehatan Muhammadiyah Gombong, Program Studi Ilmu Keperawatan; 2017.

4. Astuti FAA. Hubungan Status Gizi Dengan Kualitas Hidup Gebriatri Diposyandu Lansia Ngudi Sehat Bibis Baru Nusukan Banjarsari Surakarta [Skripsi]. Universitas Muhammadiyah Surakarta, Fakultas Kedokteran; 2012.

5. Sarnings WO. Status Gizi Dan Kualitas Hidup Lansia Di Kabupaten Barru, Kecamatan Soppengriaja Dan Mallusetasi [Jurnal Hasil Penelitian]. Universitas Muslim Indonesia Makssar, Fakultas Kedokteran; 2012.
6. Agustien AC. Hubungan Antara Kondisi Psikologis, Tingkat Kecukupan Energi, Protein Dan Tingkat Aktivitas Fisik Dengan Status Gizi Lansia Di Panti Wreda Harapan Ibu Gondoriyo Semarang [Skripsi]. Universitas Diponegoro Semarang. Program Studi Ilmu Gizi Fakultas Kedokteran; 2008.

7. Zulfitri R. Pengaruh Kesejahteraan Psikologis Lansia Terhadap Status Gizi Lansia Di Kelurahan Meranti Pandak Pekanbaru [Jurnal Hasil Penelitian]. Program Studi Ilmu Keperawatan. Universitas Riau; 2010.

8. Ningsih W. Hubungan Dukungan Keluarga Dengan Status Gizi Pada Lansia Di Dusun Jodog Kelurahan Gilangharjo Pandak Bantul Yogyakarta[Skripsi]. Sekolah Tinggi Ilmu Kesehatan Jendral Achmad Yani Yogyakarta. Program Studi Ilmu Keperawatan; 2013.

9. Suryanti, dkk. Hasil Status Gizi Dengan Tempat Tinggal Pada Lansia Di Kota Pekan Baru [Jurnal Hasil Penelitian]. Fakultas Kedokteran Dan Ilmu Kesehatan. Universitas Abdurrab Pekan Baru; 2017. 


\section{LAMPIRAN}

Tabel 1. Distribusi Responden Berdasarkan Kelompok Umur, Jenis Kelamin, Pendidikan, Status Pekerjaan dan Status Tinggal Di Wilayah Puskesmas Madising Na Mario Kota Parepare

\begin{tabular}{lcc}
\hline \multicolumn{1}{c}{ Karakteristik } & $f$ & $\%$ \\
\hline Kelompok Umur & & \\
60-64tahun & 26 & 29.2 \\
65-69tahun & 29 & 32.6 \\
70-74tahun & 34 & 38.2 \\
\hline Jenis Kelamin & & \\
laki-laki & 37 & 41.6 \\
Perempuan & 52 & 58.4 \\
\hline Pendidikan & & \\
Tidak tamat SD & 22 & 24.7 \\
SD & 30 & 33.7 \\
SMP & 20 & 22.5 \\
SMA & 14 & 15.7 \\
Sarjana (S1) & 3 & 3.4 \\
\hline Status Pekerjaan & & \\
Tidak bekerja & 71 & 79.8 \\
Wiraswasta & 16 & 18.0 \\
Buruh cuci & 1 & 1.1 \\
Buruh/kuli bangunan & 1 & 1.1 \\
\hline Status Tinggal & & 7.9 \\
Sendiri & 7 & 16.9 \\
Pasangan & 15 & 75.3 \\
keluarga besar & 67 & 100 \\
\hline Total & 89 & \\
Sumber : Datapriner & & \\
\hline & & \\
\hline & & \\
\hline
\end{tabular}

Sumber : Data primer (2018)

Tabel 2. Distribusi Responden Berdasarkan Status Gizi

\begin{tabular}{lll}
\hline Status Gizi & $F$ & $\%$ \\
\hline Normal $(18.5-25.0)$ & 63 & 70,8 \\
Tidak normal $(<18.5,>25.0)$ & 26 & 29,2 \\
\hline Total & 89 & 100,0 \\
\hline
\end{tabular}

Sumber : Data primer (2018)

Tabel 3. Distribusi Responden Berdasarkan Kualitas Hidup Lansia Di Tinjau Dari Kesehatan Fisik, Kesehatan Psikologis, Kondisi Sosial,dan Kondisi Lingkungan

\begin{tabular}{lll}
\hline Kualitas Hidup & $F$ & $\%$ \\
\hline Kesehatan Fisik &
\end{tabular}




\begin{tabular}{lcc} 
Baik & 36 & 40,4 \\
Tidak Baik & 53 & 59,6 \\
\hline Kesehatan Psikologis & & \\
Baik & 39 & 43,8 \\
Tidak Baik & 50 & 56,6 \\
\hline Kondisi Sosial & & \\
Baik & 37 & 41,6 \\
Tidak Baik & 52 & 58,4 \\
\hline Kondisi Lingkungan & & \\
Baik & 68 & 76,4 \\
Tidak Baik & 21 & 23,0 \\
\hline Total & 89 & 100 \\
\hline Sumb : Data prim
\end{tabular}

Sumber : Data primer (2018)

Tabel 4. Distribusi responden berdasarkan hubungan status gizi dengan kualitas hidup pada lansia ditinjau dari kesehatan fisik.

\begin{tabular}{|c|c|c|c|c|c|c|c|}
\hline \multirow{3}{*}{$\begin{array}{c}\text { Kesehatan } \\
\text { Fisik }\end{array}$} & \multicolumn{7}{|c|}{ Status Gizi } \\
\hline & \multicolumn{2}{|c|}{ Normal } & \multicolumn{2}{|c|}{ Tidak normal } & \multicolumn{2}{|c|}{ Total } & \multirow{2}{*}{ Nilai } \\
\hline & $\mathrm{n}$ & $\%$ & $\mathrm{~N}$ & $\%$ & $\mathrm{~N}$ & $\%$ & \\
\hline Baik & 20 & 55,6 & 16 & 44,4 & 36 & 100,0 & \\
\hline Tidak baik & 43 & 81,1 & 10 & 18,9 & 53 & 100,0 & 0,009 \\
\hline Total & 63 & 70,8 & 26 & 29,2 & 89 & 100,0 & \\
\hline
\end{tabular}

Sumber : Data primer (2018)

Tabel 5. Distribusi responden berdasarkan hubungan status gizi dengan kualitas hidup pada lansia ditinjau dari kesehatan psikologis.

\begin{tabular}{llllllll}
\hline \multirow{2}{*}{$\begin{array}{l}\text { Kesehatan } \\
\text { Psikologis }\end{array}$} & \multicolumn{6}{c}{ Normal } & \multicolumn{5}{c}{ Tidak normal } & Total & \multirow{2}{*}{ Nilai } \\
\cline { 2 - 7 } & $\mathrm{n}$ & $\%$ & $\mathrm{n}$ & $\%$ & $\mathrm{n}$ & $\%$ & \\
\hline Baik & 26 & 66,7 & 13 & 33,3 & 39 & 100,0 & \\
$\begin{array}{l}\text { Tidak } \\
\text { baik }\end{array}$ & 37 & 74,0 & 13 & 26,0 & 50 & 100,0 & 0,450 \\
\hline Total & 63 & 70.7 & 26 & 29.2 & 89 & 100,0 & \\
\hline
\end{tabular}

Sumber : Data primer (2018)

Tabel 6. Distribusi responden berdasarkan hubungan status gizi dengan kualitas hidup pada lansia di tinjau dari kondisi sosial.

\begin{tabular}{ll}
\hline Kondisi & Status gizi
\end{tabular}




\begin{tabular}{llllllll}
\hline Sosial & \multicolumn{2}{l}{ Normal } & \multicolumn{2}{l}{ Tidak normal } & \multicolumn{2}{l}{ Total } & Nilai \\
\cline { 2 - 6 } & $\mathrm{n}$ & $\%$ & $\mathrm{n}$ & $\%$ & $\mathrm{n}$ & $\%$ & \\
\hline Baik & 21 & 56,8 & 16 & 43,2 & 37 & 100,0 & \multirow{2}{*}{0,014} \\
Tidak baik & 42 & 80,8 & 10 & 19,2 & 52 & 100,0 & $<0,05$ \\
\cline { 1 - 5 } Total & 63 & 70,8 & 26 & 29,2 & 89 & 100,0 & \\
\hline
\end{tabular}

Sumber : Data primer (2018) 